\title{
Scotland: devolved government and national politics
}

Devolved government in Scotland started as a radical innovation in bringing government closer to citizens, and its development has generated great expectations including strong pressures for and against the Scottish Parliament and government becoming the core of a newly independent state. Malcolm Harvey and the Democratic Audit team explore how democratically and effectively these central institutions have performed.

\section{What does democracy require of Scotland's devolved Parliament and government?}

The legislature should normally maintain full public control of government services and state operations, ensuring public and parliamentary accountability through conditionally supporting the government, and articulating reasoned opposition, via its proceedings.

$\downarrow$ The Scottish Parliament should be a critically important focus of Scottish political debate, particularly (but not limited to) issues of devolved competence, articulating 'public opinion' in ways that provide useful guidance to the government in making complex policy choices.

$\downarrow$ Individually and collectively legislators should seek to uncover and publicise issues of public concern and citizens' grievances, giving effective representation both to majority and minority views, and showing a consensus regard for the public interest.

$\downarrow$ The Scottish government should govern responsively, prioritising the public interest and reflecting Scotland's public opinion.

Scotland's law courts and legal system have always been separate from those in England and Wales, and culminate in the High Court in Edinburgh. However, the UK Supreme Court remains the key legal arbiter of relations between the UK and Scottish governments. Many of the founding ideas for Scotland's Parliament and government were defined by the Scottish Constitutional Convention (1989-95), and implemented in the Blair government's devolution settlement, overwhelmingly endorsed by Scottish voters in 1997. The core institutions are a Scottish Parliament of 129 MSPs, elected by a broadly proportional 
representation system - the additional member system (see Chapter 2.2). A Scottish executive was set up to run all the devolved policy areas, using a directorate structure (instead of the separate departments found in Whitehall). Its policy responsibilities have steadily expanded and the now Scottish government supervises the £58bn of spending in Scotland that are devolved functions. Most domestic spending (on education, health, transport, housing, local government and the economy) is devolved. The key areas excluded from their control - and which would accrue only to an independent Scotland remain most social security, most major taxation, defence and foreign affairs. However, as a result of greater devolution pledges made during the 2014 referendum campaign, the Edinburgh Parliament now has significant tax-raising powers and also runs some significant social security benefits domestically (see Chapter 5.6). The government is currently headed by the Scottish National Party (SNP) leader, First Minister Nicola Sturgeon. She has a small cabinet (12 members), plus another 13 ministers, all drawn from the Parliament.

\section{Recent developments}

Despite electing MSPs via proportional representation, which tends to stabilise political alignments, Scottish politics has undergone a period of significant political and constitutional upheaval over the past half decade. In 2011 the SNP returned 69 of the 129 MSPs - a majority government, for the first time - providing the crucial catalyst for Scotland's independence referendum in 2014. The SNP proposition that Scotland should secede from the UK (also supported by the Greens) was opposed by all the main UK parties in Scotland and was defeated by $55 \%$ to $45 \%$.

Nevertheless, far from killing off the SNP and their raison d'être, the strong campaigning momentum of the referendum period and its aftermath saw SNP membership increase fivefold, from 25,000 before the referendum to around 125,000 in the six months after it. At the UK general election in 2015, the SNP went on to increase their seats from six in 2010 to 56 of Scotland's 59 seats, taking 49.97\% of the vote in the process. This was a high watermark and in the May 2016 Scottish Parliament election the SNP won 63 seats, falling two shy of the 65 required for a majority, but retaining government office with Green support. The SNP subsequently lost a third of its Westminster seats in 2017 (down from 56 to 35), with the Conservatives and Labour both gaining a lot at their expense.

The Scottish independence referendum also began critical changes in the fortunes of Scottish Labour and the Scottish Conservatives. Labour was first ousted from control of the Scottish executive in 2007, and its subsequent history has been nothing short of catastrophic. Since then the party has had 11 different leaders (five of those in a caretaker role) and its previous dominance of Scottish politics has rapidly leached away. A key stage was reform of the electoral system for Scottish local government, often Labour-dominated, with the single transferable vote introduced by Labour with Liberal Democrat support in 2006. At three elections (2007, 2012 and 2017) Labour's previously dominant control of councils and councillors has been drastically eroded by the SNP. Increasingly without its traditional hegemony in central Scotland's local authorities, Labour's decline accelerated under PR elections for the Scottish Parliament. 
Figure 1: Percentage of Scottish Westminster seats won by each party 1997-2017

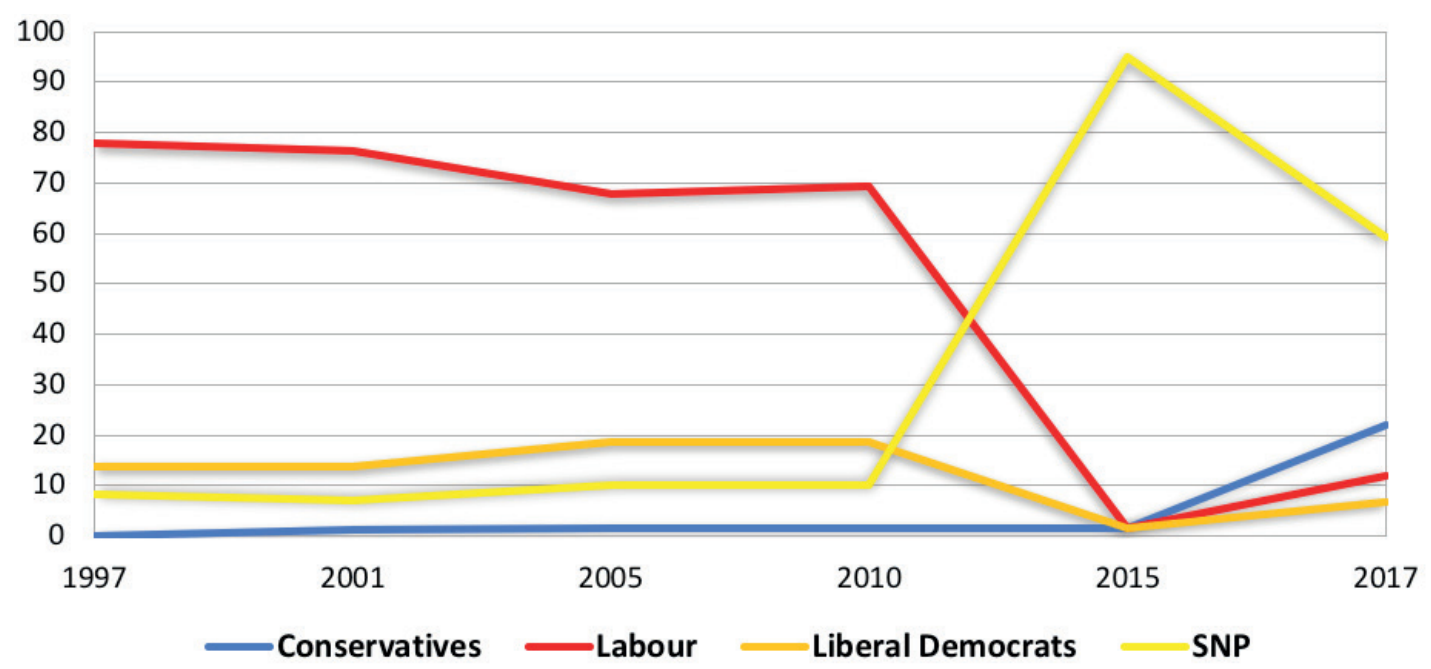

Source: UK Election Statistics 1918-2017, Parliament UK

Figure 2: Percentage of Scottish Parliament seats won by each party 1999-2016

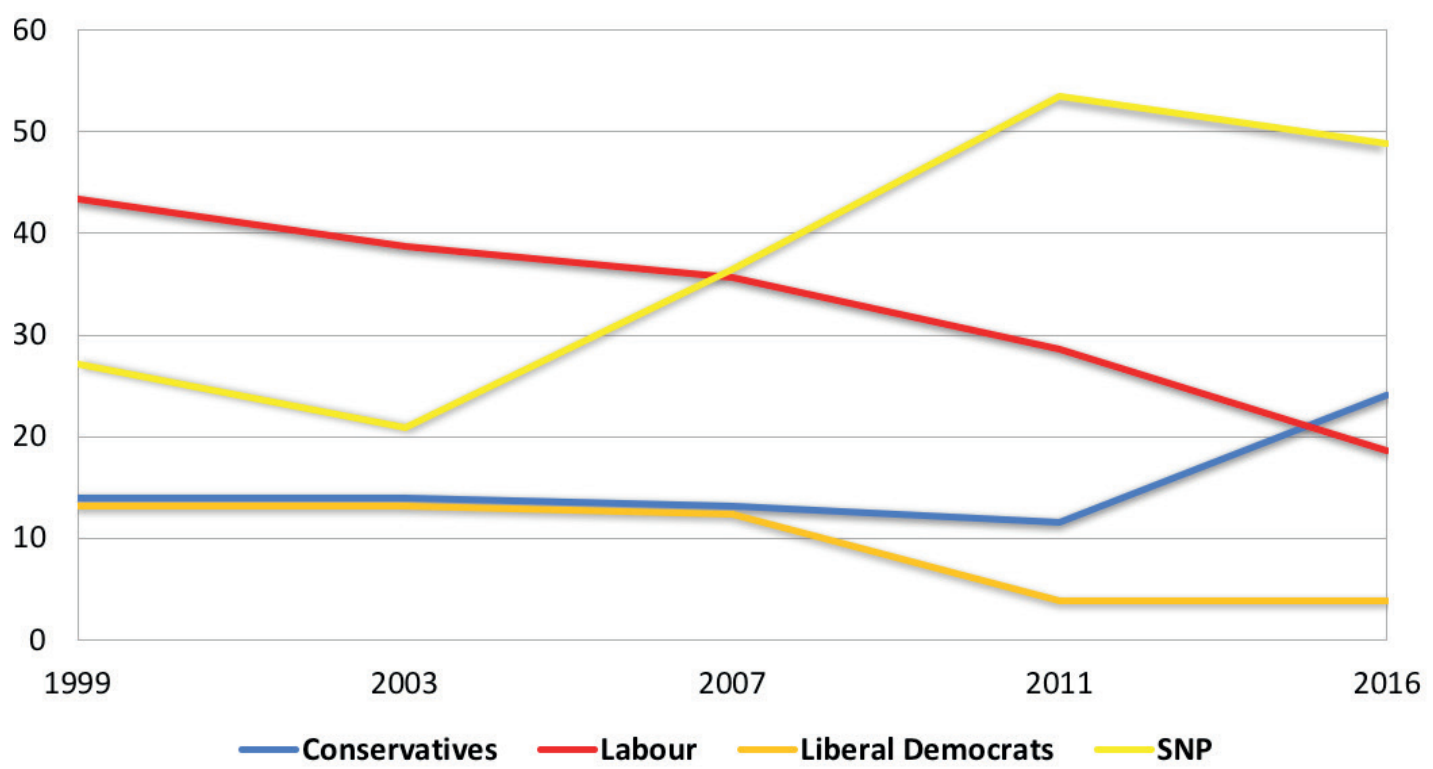

Source: UK Election Statistics 1918-2017, Parliament UK

Figure 1 shows how suddenly and completely Labour's Westminster predominance was abruptly terminated in 2015, with the party losing all but one of the 41 seats it held in 2010. While Labour won back six more seats in 2017 (up from one), for a party that had dominated Scottish politics for nearly half a century, this remained a stunning reversal of fortune. Signs of this decline were already apparent under Gordon Brown's premiership, but the shock effect was accentuated by weak UK Labour leaders (Miliband and Corbyn before 2017), who had little electoral appeal in Scotland. 
Labour's once equally strong unionism was squeezed in the 2014 referendum campaign by the SNP's embrace of social democratic approaches, and divisions amongst Labour and left/green voters, members and trade unionists on how to vote. The party leadership found themselves in a constitutional lose-lose situation between the SNP's clear nationalist option and the Conservatives' unabashed unionism. Labour has tried to float a position somewhere between the two, discussing increased autonomy, 'devo-more', and, most recently, even federalism. But the issue has become so polarised that there are now few voters in the middle ground. Labour achieved some gains against the SNP in 2017, and has since selected Richard Leonard as the Scottish Labour Party leader, who is broadly supportive of Corbyn.

Meanwhile, since the 2014 referendum the Scottish Conservatives have staged a significant revival, becoming the main opposition party to the broadly social democratic SNP. In 2017 , the Scottish Conservatives' leader, Ruth Davidson, ran a considerably more successful campaign than Theresa May. In the Scottish Parliament, as a result of the proportional electoral system that they had continually opposed, the Conservatives have moved sharply back from the electoral decline of the 1990s to be the official opposition. This was largely because their clearer and complete opposition to independence suddenly projected them as the safer option in defending the UK union. In 2017 the Conservatives were also the second party in Scotland in terms of Westminster seats, holding 13 to Labour's seven and the Liberal Democrats' four.

\section{Strengths, Weaknesses, Opportunities, Threats (SWOT) analysis}

Current strengths
The Scottish Parliament has long held itself
to be a parliament that is transparent in its
operation, and the stringent measures it
took to provide for registering interests of its
members meant that it has largely avoided
the negativity that befell Westminster in the
wake of the MPs' expense scandal.

\section{Current weaknesses}

Parties in the Scottish Parliament operate strict party discipline, like the House of Commons. MSPs rarely rebel on whipped votes. During the 2011-16 majority SNP government, many critics complained that rigorous SNP discipline reduced the Parliament to a residual role akin to the stunted functions of the Westminster Parliament - subject to the dominance of the executive. Some observers have argued that the majoritarian culture of Westminster has transferred to and endured within the devolved legislatures. 


\section{Current strengths}

As a key aspect of set-piece politics, the weekly jousting session that is First Minister's Questions provides opposition parties with the opportunity to hold the government to account.

The establishment of family-friendly hours - parliamentary business takes place from Tuesday to Thursday, 9am-6pm, with infrequent exceptions - means that members have a clearly established working pattern, allowing for better work-life balance, the ability to spend more time with family or other outside interests.

Electronic voting allows for decisions to be made quickly and records to be announced without the need for physical divisions that operate in the House of Commons. The Parliament also has modern IT built into all its operations.

\section{Current weaknesses}

The committee system of the Scottish

Parliament, established to fulfil the function of both Westminster bill and select committees, has proved ineffectual in scrutinising legislation and holding government ministers to account. Members are assigned to committees based just on party strength in the wider parliament.

First Minister's Questions provides a setpiece session, albeit in a tired format. But it does not clearly fulfil objectives of enhancing scrutiny or accountability. Questions and answers frequently revert to partisan bickering, especially on the unresolved constitutional questions around independence.

The additional member system for electing MSPs creates a distinction between constituency and regional list MSPs, although issues around 'two classes' of members are less evident than in Wales. Some list MSPs have been accused of 'targeting' citizens' cases in a single local constituency of their region, with the next parliamentary election in mind. Potentially then, their regional constituents elsewhere might not be as well represented as those in the target constituency.

The operation of the additional member system has created a closed party system in Scotland. No new parties have entered the legislature since 2003. There is no official 'threshold' to gain list MSPs (as there is in the operation of the German AMS electoral system), but because top-up regions are quite small, parties normally need to secure between $5 \%$ and $9 \%$ of the list vote, in order to secure MSPs at this stage.

The Parliament has few ethnic minority MSPs. The first was elected in 2007 , and only four have succeeded ever, each initially elected as regional members for Glasgow. 


\section{Future opportunities}

The vote to leave the European Union has altered the dynamics of the Scottish constitutional debate. Given the nature of the 'reserved powers model' of devolution which established the Scottish Parliament, the 'repatriation' of powers from Brussels may provide the Scottish Parliament (and government) with the opportunity to accrue most of these powers, providing it with extensive competences. The extent of these new powers is a matter of dispute with the UK government.

The return to a new SNP minority government from 2016 may mean that Parliament can reassert itself, regaining a clearer role in scrutinising government legislation and holding the government to account.

\section{Future threats}

Scotland has only a small, uni-cameral legislature. There is no upper chamber to act as a check or balance on the Parliament misoperating or over-reaching its powers.

With or without independence, the Scottish Parliament faces major issues about its capacity to deal with the significant increases in powers that have been delivered or are promised. When 25 government ministers and three different main opposition party front benches are removed (at least another 35 MSPs here), only a limited number of members remain to fill existing committee seats. (The problem would worsen postindependence, with more ministers and committees needed for five main additional functions.)

The Presiding Officer's 'MOT' review of the Scottish Parliament (see below) and willingness to actively examine the operating procedures is both timely and a recognition that there are ways in which the parliament can improve.

\section{Has the Scottish Parliament matched its own democratic ideals?}

Following the success of the devolution referendum in 1997, a Consultative Steering Group on the Scottish Parliament was established to provide recommendations on how the Parliament should operate: how it would be elected, the Standing Orders that would operate, and the key principles it would operate under. They provided an ambitious agenda for an apparently more consensual democratic approach. A first 'key principle' was (unexceptionally) that the Scottish executive (now Scottish government):

'should be accountable to the Scottish Parliament, and the Parliament and executive should be accountable to the people of Scotland'. 
Three more far-reaching 'key principles' required that the Scottish Parliament:

'should embody and reflect the sharing of power between the people of Scotland, the legislators and the Scottish executive;

$\checkmark$ should be accessible, open, responsive, and develop procedures which make possible a participative approach to the development, consideration and scrutiny of policy and legislation;

$\downarrow$ [and] in its operation and its appointments should recognise the need to promote equal opportunities for all'.

On each of these three measures, how has the Parliament performed? The picture is rather mixed. Power-sharing between the executive and the legislature was most obvious during the SNP's period of minority government between 2007 and 2011; and, again, since the 2016 election. These periods gave the Scottish Parliament a clear role in adapting, challenging and scrutinising government proposals. During the first two sessions - under the Labour-Liberal Democrat coalitions - Parliament's role was more limited, though some pieces of private members' legislation piloted by Tavish Scott and Tommy Sheridan were passed into law.

However, from 2011 to 2016 there was an overall SNP majority in the legislature. This was a period characterised by much more in the way of executive dominance (more in line with the 'Westminster system' model). The Scottish Parliament was reduced to a rubber-stamping role as the (incredibly disciplined) SNP government utilised its majority of MSPs to full effect.

On accessibility, the Scottish Parliament appears to score more highly. It has a wellutilised public petitions committee and a clear and transparent process of legislating, and it symbolically meets inside a building in which most rooms are glass-fronted. However, public engagement in its elections continues to hover around the $50 \%$ mark - significantly lower than the level of UK elections (though the independence referendum did see a record $84 \%$ turnout).

When it was established in 1999, the Scottish Parliament was one of the most genderbalanced parliaments in Europe, with only the Scandinavian states returning more female representatives. However, since then, and despite significant (but voluntary) mechanisms being adopted by several political parties, female representation has fallen. Ethnic minority people, and those who identify as having a disability, have also not become MSPs in any significant numbers, so the Parliament's success on promoting equality has been limited here. But it does maintain 'family-friendly' working hours, with almost all parliamentary business taking place from Tuesday to Thursday in office hours. This allows MSPs to spend more time with family, their constituencies or outside interests - one MSP was a qualified referee and regularly featured at Scottish and European games (since becoming an MP in 2017, he has been criticised for absences from Westminster in key debates). Chamber business very rarely extends beyond $6 \mathrm{pm}$ - in sharp contrast with the late-night sessions that are frequently a part of the House of Commons business.

In terms of accountability, MSPs themselves have to adhere to a strict Code of Conduct, and the Standards Committee can investigate any breaches of this. Scottish government ministers are required to respond to questions and appear in front of parliamentary committees regularly in order to provide information on their brief. However, ministers 
can be more or less accommodating - and the questions can be more or less pointed depending on the nature of the query and the party which is asking it. There is a vigorous First Minister's question time.

On becoming Presiding Officer after the 2016 Scottish Parliament election, Ken Macintosh announced that the parliament should undergo a 'MOT' to determine how well it operated and what could be improved. A Commission, chaired by John McCormick, reported in June 2017 examined the ways in which the parliament can:

$\downarrow$ be assured it has the right checks and balances in place for the effective conduct of parliamentary business;

increase its engagement with wider society and the public; and

clarify its identity as distinct from the Scottish Government.

Its recommendations included strengthening committees by introducing direct elections for their conveners (chairs) by Parliament and offering additional salaries for them, as in the House of Commons, as well as improving the time and resources committees had available. It also recommended strengthening the Parliament's processes for pre- and post-legislative scrutiny, increasing the stages from three to five, and removing scripted diary questions from First Minister's Questions.

\section{Is Scotland a 'dominant party system'?}

The recent electoral dominance of the SNP led several political commentators and politicians - most notably Adam Tomkins, the newly elected Conservative MSP - to complain that Scotland has become a 'one-party state'. This characterisation is clearly flawed. A one-party state is a very different thing from 'a dominant party system', where regular competitive elections are held, but the same party always wins - as happened in Scotland in the period of Labour hegemony. But what this exaggeration does point to is that the relatively small Parliament is easily dominated by the executive if one party has an overall majority. For instance, in the period 2011-16, when the SNP formed a majority government, this status guaranteed the party a majority of the institution's committee convenorships (important for determining the business and agendas of committees) and, crucially, a majority of members on each committee. So the government not only had a majority in the chamber - where votes on stages one and three of legislation take place - they also had majorities in committees, where stage two is debated and amendments raised. This repetition of the Westminster model (despite PR elections) was accentuated by loyal SNP backbenchers keen to assist the government's agenda.

\section{Scotland, Brexit and a second referendum}

The UK-wide vote to leave the European Union in June 2016 contrasted strongly with Scotland's electorate voting $62 \%$ to $38 \%$ to remain in the EU, highlighting a clear divergence in public attitudes in Scotland from those in England and Wales. The SNP argues that the fact Scotland will be forced to leave the EU with the rest of the UK, despite voting differently, shows that Scotland is not an 'equal partner' in the UK, and that its 'voice 
is not being heard'. It is also in dispute with the UK government about whether the Scottish government or Westminster should be responsible for some key policy areas that will return to UK control from the EU - with the Scottish government arguing that Westminster is undertaking a 'power grab' through the EU Withdrawal Act. The Edinburgh Parliament passed its own Continuity Bill, a Scottish equivalent of the EU Withdrawal Act, which the UK government is challenging. The case will be decided by the Supreme Court in autumn 2018 (see Chapter 5.6). The referendum outcome also puts the issue of a second constitutional referendum 'back on the table', with the SNP arguing that 'only independence' can ensure that the Scottish electorate are not overruled by the wider UK electorate.

The SNP government produced a document which outlined options for Scotland to retain some form of access to the EU and attempted to get the UK government to examine them. However, the May government's increasing momentum towards a 'hard Brexit' up to the 2017 general election produced only bruising rebuffs for Sturgeon's suggestions. These led in turn to the First Minister announcing that a second independence referendum should be held before the UK leaves the EU in April 2019 - a timetable that has been flatly rejected by the Conservatives, who put the earliest feasible date as 2020 - by which time Brexit would be a fait accompli. In the short term, opinion polls show that Scotland's voters are opposed to a second referendum, and would split quite evenly but so far not convincingly for independence. The polls also suggested that there is a limited link between support for membership of the EU and support for independence - meaning that the issue of Brexit may not be the tipping point that the SNP hope for.

However, in May 2018 the SNP released a report from an internal party commission (the Wilson report) which outlined what it claimed was a sustainable future for an independent Scotland in economic terms. The party was clearly seeking to revive the idea of a second referendum campaign, yet by August 2018 experts still felt that the public opinion support to buttress such a move was not yet there. SNP supporters claim that the starting point for an extended debate is much more favourable now for the independence cause than it was at the start of the 2012-14 campaign, which is true, so that 'movement effects' in a renewed second campaign could create a majority, though this remains unclear.

Dr Malcolm Harvey is a Teaching Fellow at the University of Aberdeen and an associate fellow of the Centre on Constitutional Change. 